\title{
Neoproterozoic geotectonic evolution of Tocantins Structural Province, Central Brazil
}

\author{
Adelir José Strieder ${ }^{\mathrm{a}, *}$, Marcos Tadeu de Freitas Suita ${ }^{\mathrm{b}}$ \\ ${ }^{a}$ Department of Mining Engineering-EE-Federal University of Rio Grande do Sul (UFRGS) Cx. P. 958 CEP 90.001- \\ 970 Porto Alegre, RS Brazil \\ ${ }^{\mathrm{b}}$ Mining Department-EM-Federal University of Ouro Preto (UFOP) CEP 53.400-000 Ouro Preto, MG Brazil
}

Received 5 March 1997; accepted 9 February 1998

\begin{abstract}
Tocantins Structural Province (TSP) is the main tectonic feature in Central Brazil. It separates two main cratonic areas (former continental plates): the Amazonian Craton to the West and the São Francisco Craton to the East. Recent geochronological data (U-Pb and $\mathrm{Sm}-\mathrm{Nd}$ ) and structural studies show that the actual structural framework of the province was developed during the Neoproterozoic. It is herein proposed that Brasiliano Orogenic Cycle in the TSP was developed in four broad tectonic stages: 1) an ocean opening stage began possibly $1270 \mathrm{Ma}$; 2) an island-arc system development stage started $1000 \mathrm{Ma}$ and its amalgamation lasted until ca. $800 \mathrm{Ma}$; 3) a continental collision stage began ca. $800 \mathrm{Ma}$ with the accretion of the island-arcs to the upper Amazonian plate, the closure of the Goiás Ocean and the development of a foreland basin upon the lower São Francisco plate; and 4) a post-collisional stage (650-500 Ma) with the development of transcurrent faults (Transbrasiliano lineaments), back-thrust reverse faults, and intrusion of alkalic granitic plutons. (C) 1999 Elsevier Science Ltd. All rights reserved.
\end{abstract}

\section{Introduction}

The Tocantins Structural Province (TSP, Almeida et al., 1981) is an elongated fold and thrust belt located in Central Brazil (Fig. 1). It is characterized by a specific disposal of structural lineaments (Fig. 2). In its northern part, the lineaments are roughly $\mathrm{N}-\mathrm{S}$; near the $15^{\circ} 30^{\prime} \mathrm{S}$ parallel, however, the western lineaments turn toward the west and then toward the south. The eastern lineaments are aligned SSE despite minor inflections and reach the $21^{\circ} \mathrm{S}$ parallel, where they turn sharply toward the west for $250 \mathrm{~km}$ and then sharply toward the ESE defining a tectonic syntaxis (Serra da Canastra Inflection, Strieder and Nilson, 1993b). The lineaments rising from this tectonic syntaxis trend ESE for more than $350 \mathrm{~km}$ and turn toward the SW to make up the Cunha

\footnotetext{
* Corresponding author. E-mail: adelir@lapes.ufrgs.br 


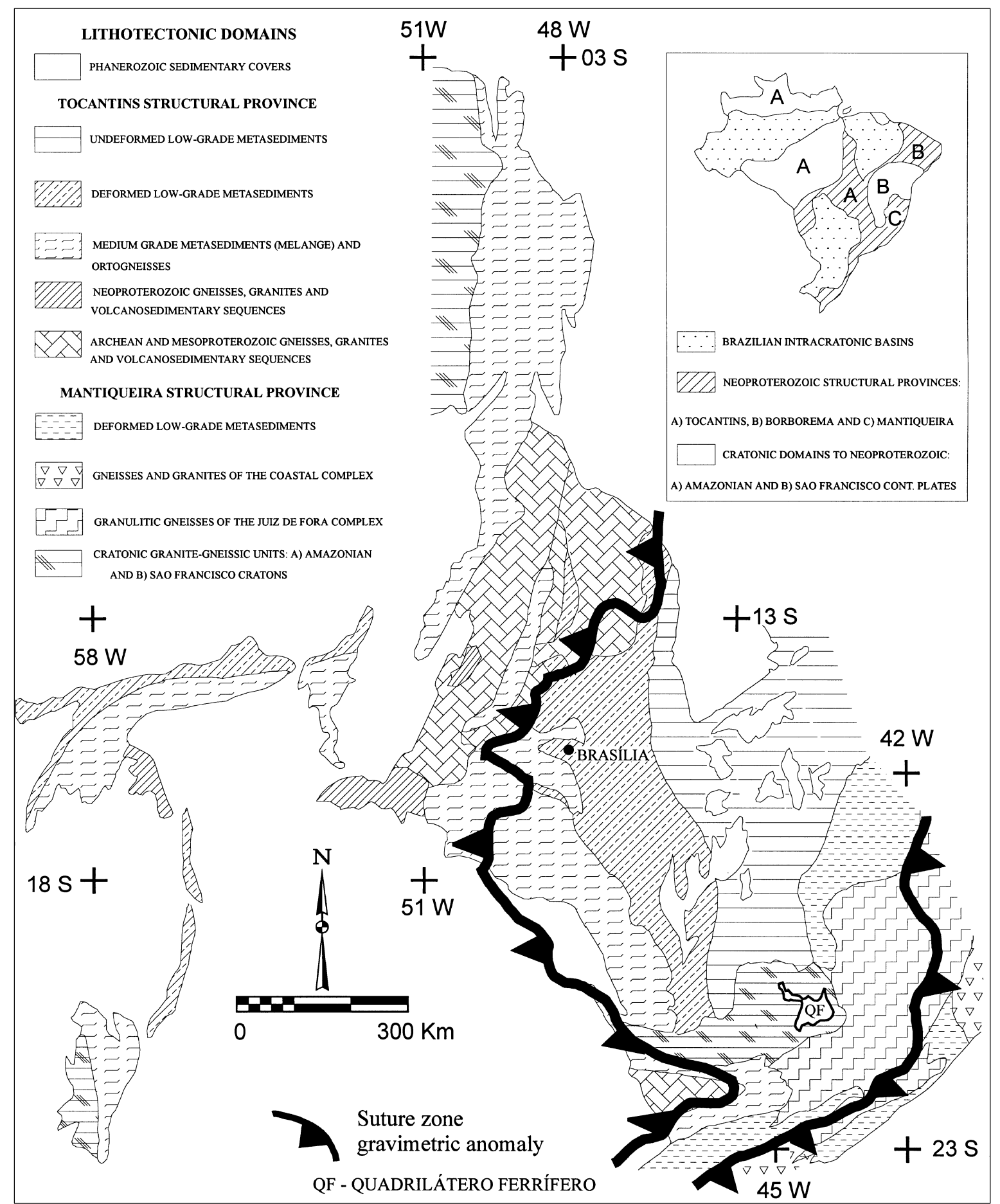

Fig. 1. Lithotectonic sketch of the Tocantins and Mantiqueira structural provinces, Brazil (after Strieder, 1993a, 1993b). 


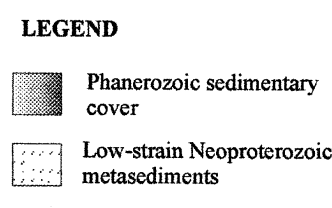

Mesoproterozoic Mafic-ultramafic Layered Complexes

Mesoproterozoic A-type granites

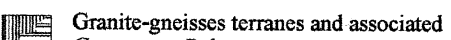
Greenstone Belts sequences

Pre-brasiliano cratonic domains

Approximate location of the main thrust faults in the BSP-TSP

Generalized structural lineaments in the high-strain domains

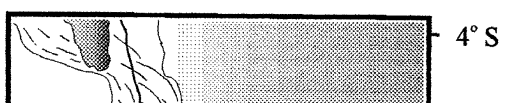

$4^{\circ} \mathrm{S}$

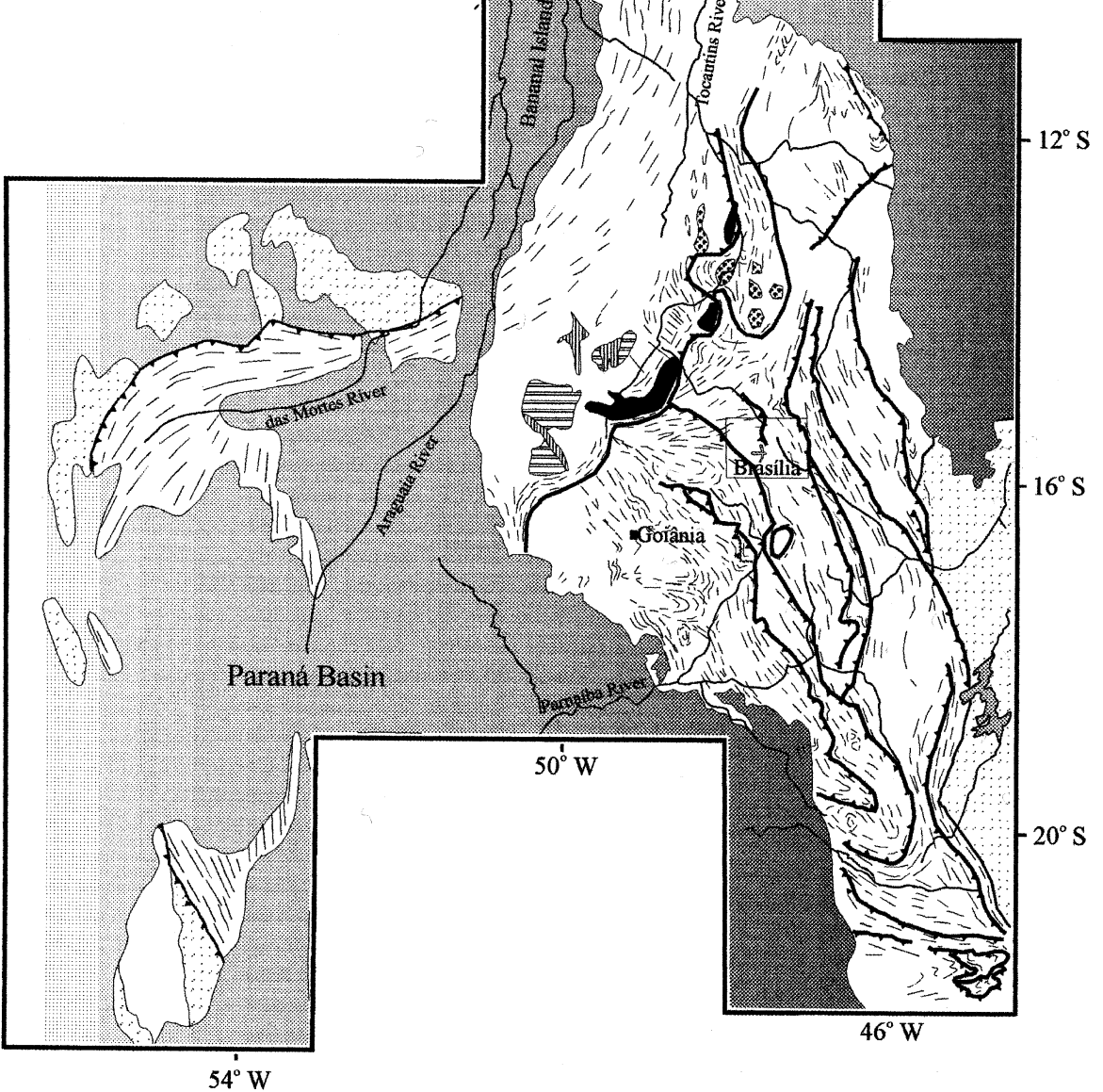

Fig. 2. Generalized lineament sketch of the main structural elements in the TSP. The structural lineaments in the eastern sub-province (Brasília subprovince) are from Strieder (1993a); the structural lineaments of the western ParaguaiAraguaia subprovince are modified from Hasui and Costa (1990) and the map from Schobbenhaus Filho et al. (1984); the structural lineaments from Cunha de Guaxupé region are modified from Hasui et al. (1990). 
de Guaxupé (Hasui et al., 1990). Both lineament branches of the TSP are built mainly upon metasedimentary rocks and have been named Paraguay-Araguaia (the western) and Brasília (the eastern) subprovinces (Strieder, 1993a). These provinces are separated by an older granite-gneissic belt, large metamorphosed and deformed mafic-ultramafic and granitic intrusions, and Archean and Proterozoic volcano-sedimentary units.

Regional geological survey at TSP began in 1960's and the first tectonic scheme was proposed by Almeida (1967), on the basis of Geosynclinal theory. A later tectonic framework distinguished 1) the Goiás Median Massif formed by the oldest rock units, 2) the Uruaçuano Belt composed by Araxá metasedimentary unit with alpine-type mafic and ultramafic bodies earlier envisaged as the eugeosynclinal counterpart of the 3) eastern fold belt (Brasilia Belt), and the 4) western fold belt (Paraguay-Araguaia Belt). This framework was based on the first geochronological dating programmes (Almeida, 1968; Hasui and Almeida, 1970; Almeida et al., 1976). In the end of 1970's and during the first half of the 1980's, the tectonic setting of the TSP was described on the basis of the Mobile Belt hypothesis (Almeida et al., 1980; Lesquer et al., 1981; Haralyi and Hasui, 1981; Cordani and Brito Neves, 1982). By this time, the discussion was focused on the operation of one (Brasiliano) tectonic cycle (Cordani and Brito Neves, 1982), or two (Uruaçuano and Brasiliano) tectonic cycles (Almeida et al., 1977; Almeida et al., 1980; Haralyi and Hasui, 1982). In the second half of the 1980's, Hasui and Haralyi (1985) reinterpreted strong linear gravimetric anomalies as the locus of a continental suture on the basis of the plate tectonics; however, they regarded the main TSP features as long-lived structures inherited and reactivated since Archean times. Hasui and Haralyi (1985) also interpreted the TSP tectonic framework as evolved by superposed oblique convergence episodes in an ensialic environment. Thus, the dispute about the TSP evolution was focused on repeated movements along preferential structures during several tectonic cycles (e.g. Marini et al., 1984; Hasui et al., 1994), or on the amalgamation and juxtaposition of different older continental fragments in the Brasiliano orogenic cycle (Brito Neves and Cordani, 1991).

Nowadays, several rigorous geochronological results have been published (e.g.: Pimentel and Fuck, 1992; Pimentel et al., 1991a 1991b, 1992, 1993a, 1993b; Ferreira Filho et al., 1994; Suita et al., 1994a, 1994b) that constrain the Neoproterozoic geotectonic evolution of TSP. Also, recent petrochemical results on alpine-type bodies, tectonically emplaced in the Araxá metasediments, permit to recognize an ophiolitic melange related to the Hasui and Haralyi's (1985) linear gravimetric anomaly (Strieder and Nilson, 1992a). Strieder (1993b) also described a number of structural inflections in the Brasília subprovince, similar to those described by Coward and Potts (1983), that are at high angles to the linear gravimetric anomaly and point to frontal collisional tectonics. Fuck (1994) also presented a brief framework to the TSP, describing the inner composition of each tectonic entity; however, he did not address considerations on timing and structural evolution of the province.

This paper presents an overview of the Neoproterozoic tectonic evolution of the TSP. It is based on structural features and constrained mainly by high precision $\mathrm{U}-\mathrm{Pb}$ and $\mathrm{Sm}-\mathrm{Nd}$ ages. The operation of a complete orogenic cycle during the Neoproterozoic of the TSP is related to agglutination processes that led to the formation of the Gondwana Supercontinent. The first section deals with the nature of the pre-Neoproterozoic continental lithosphere (i.e. the cratonic areas related to the Brasiliano Orogenic Cycle), in order to examine the nature of Goiás Median Massif and the time constraints for the presence of an oceanic lithosphere in that region. The second section deals with the Neoproterozoic structural framework, discusses the main lithotectonic units 
of the TSP and comments the observed structures. The third section considers the geochronological constraints of the Neoproterozoic Brasiliano Orogenic Cycle in the TSP. Finally, an integrated discussion of all these data is used to build up a tectonic scenario as to where TSP framework was developed.

\section{The intervening continental lithosphere}

The TSP developed between two continental areas (plates) during the Meso- to Neoproterozoic of Central Brazil: the Amazonian (ASP) and São Francisco (SFSP) structural provinces (Almeida et al., 1981; Brito Neves and Cordani, 1991). The northeastern limit of the TSP is covered by the Parnaíba Basin, while the southwestern limit is covered by the Paraná Basin (Fig. 1); so, the present discussion is focused on exposed areas. The older central part of the TSP (Goiás median massif) has similarities with Amazonian and San Francisco plates (Suita and Chemale Jr., 1995). It involves several Archean tonalite-throndjemite-granite-greenstone belt associations (Danni et al., 1982), Lower to Mesoproterozoic granite-gneisses units (Hasui and Costa, 1990), large layered maficultramafic bodies (Ferreira Filho et al., 1994; Suita et al., 1994a, 1994b), some Mesoproterozoic A-type granites and their volcano-sedimentary counterparts (Pimentel et al., 1991a), and some upper Mesoproterozoic mafic-felsic intrusions and volcano-sedimentary sequences (Suita, 1996; Suita et al., 1994a, 1994b).

The most relevant lithotectonic associations in TSP (Figs 2 and 3) are the anorogenic granites and the large layered mafic-ultramafic intrusions (Barro Alto, Niquelândia and Canabrava complexes). They indicate divergent tectonic regimes associated with lithospheric stretching, that could culminate in the formation of the oceanic crust. In the Amazonian plate, it is possible to distinguish two episodes of anorogenic granite generation: 1) the lower Mesoproterozoic granites of Amazonia Central dated 1.8 to $1.4 \mathrm{Ga}$, and 2) the upper Mesoproterozoic granites of Juruena and Rondonia regions dated 1.4 to $0.9 \mathrm{Ga}$ (Dall'Agnol et al., 1987). The equivalent association in central part of the TSP is made up by the lower Mesoproterozoic granites and their volcano-sedimentary associations (Marini and Botelho, 1986; Pimentel et al., 1991a). The recent dating of the large layered maficultramafic intrusions in Central Goiás (Ferreira Filho et al., 1994; Suita et al., 1994a, 1994b) clearly defined an intracontinental divergent tectonic regime during the lower Mesoproterozoic and produced a clue on the origin of the anorogenic granites as earlier envisaged by Dall'Agnol et al. (1987) and later discussed by Nilson et al. (1994) and Suita et al. (1994a, 1994b). Suita et al. (1994b) proposed a plume mantle model for the subcrustal mafic underplating and generation of the A-type granites in the TSP during the lower Mesoproterozoic.

However, no record of an orogenic cycle is found in central TSP after the Mesoproterozoic anorogenic episode, as one can observe for the same period in Amazonian plate (Rio NegroJuruena Province: Dall'Agnol et al., 1987, 1994; Brito Neves and Cordani, 1991). Thus, it is admitted that lithospheric stretching in the TSP area does not lead to an open ocean. It is thus assumed that the lower Mesoproterozoic divergent tectonic regime has also a heterogeneous distribution and evolution.

On the other hand, some recent results point to a possible upper Mesoproterozoic divergent tectonic regime in the TSP area (Table 1). Suita et al. (1994a, 1994b) have dated a pegmatitic hornblende grabbro by U-Pb multigrains fractions and found an upper intercept of $1280 \pm 13 \mathrm{Ma}$. 


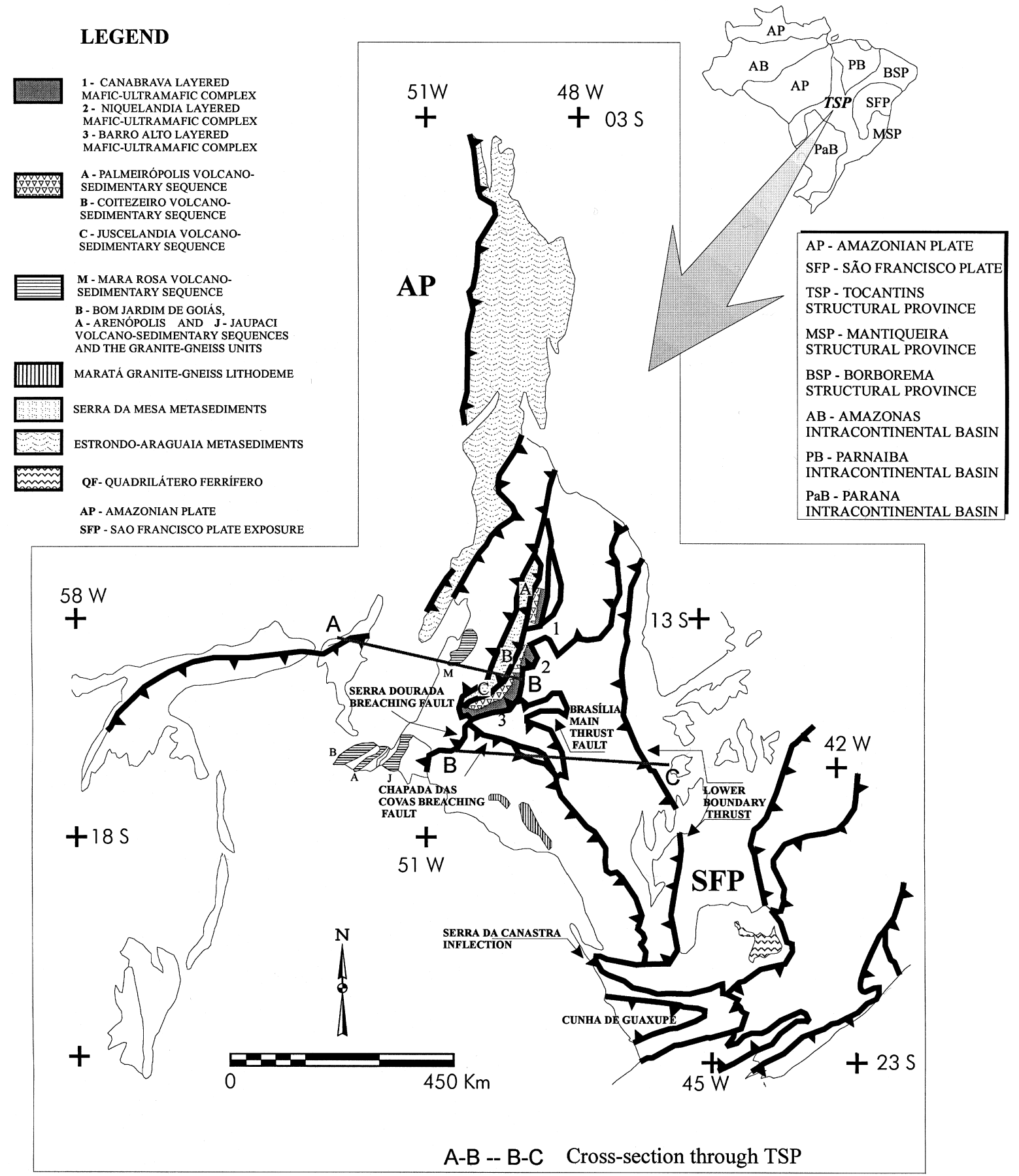

Fig. 3. Sketch of main lithotectonic units and structures used to demonstrate the tectonic framework of the TSP. The base map of this figure is the same as that of Fig. 1. See text for additional discussion. 
Table 1

Compilation of geochronological data for TSP

\begin{tabular}{ll}
\hline $\begin{array}{l}\text { Reference } \\
\text { Geochronological method } \\
\text { Results }\end{array}$ & $\begin{array}{l}\text { Geological units } \\
\text { Interpretation }\end{array}$ \\
\hline I-Emplacement of large mafic-ultramafic complexes of TSP $(1,770$ to 1,600 Ma) \\
\hline $\begin{array}{l}\text { Suita et al. (1994a, 1994b); Suita (1996) } \\
\text { U-Pb multigrains fraction }\end{array}$ & $\begin{array}{l}\text { Barro Alto Layered Mafic-Ultramafic Complex } \\
\text { Age of magma differentiation and crystallization }\end{array}$ \\
$\begin{array}{l}\text { Ferreira Filho et al. (1994) } \\
\text { U-Pb single grains }\end{array}$ & $\begin{array}{l}\text { Niquelândia Layered Intrusion } \\
\text { Minimum age of magma differentiation and } \\
\text { 1,560-1,600 Ma for the upper intercept }\end{array}$ \\
\hline
\end{tabular}

II-Emplacement of A-type intra-continental magmatic rocks (1,770 to 1,600 Ma)

Pimentel et al. (1991a)

$\mathrm{U}-\mathrm{Pb}$ single and multigrains

ca. 1,769 Ma for the upper intercept; the lower intercept is consistent with $\mathrm{Pb}$-loss during thermal events of Brasiliano episodes (ca. $650 \mathrm{Ma}$ ). Inherited components older than $2.2 \mathrm{Ga}$

1,614 to $1,574 \mathrm{Ma}$ for the upper intercept

$1,771 \pm 2 \mathrm{Ma}$ for the upper intercept

\section{Goiás Tin Province, Central Brazil}

Soledade and Sucuri granites from the eastern Rio Paranã subprovince

Serra da Mesa Granite from western Rio Tocantins subprovince

Acidic volcanics from Araí volcanosedimentary unit

III-Emplacement of mafic and felsic igneous rocks (1,300 to 1,200 Ma)

Suita et al. (1994a, 1994b); Suita (1996)

$\mathrm{U}-\mathrm{Pb}$ multigrains fraction

$1,280 \pm 13 \mathrm{Ma}$ for the upper intercept

$\mathrm{U}-\mathrm{Pb}$ multigrains fraction $1,267 \pm 9 \mathrm{Ma}$

for the upper intercept
Serra da Malacacheta intrusive gabbro

Age of magma differentiation and crystallization

Cordierite-sillimanite gneiss probably from the

Juscelândia volcanosedimentary sequence

Development of granites and of volcanosedimentary

sequences (bimodal magmatism) in an extensional regime

IV-Development of Calc-alkaline granites (950 to $800 \mathrm{Ma}$ )

Pimentel (1990); Pimentel et al. (1991b); Pimentel and Fuck (1992); Pimentel et al. (1993a); Pimentel et al.

(1993b); Viana and Pimentel (1994)

$\mathrm{U}-\mathrm{Pb}$ multigrain fraction of zircon, $\mathrm{Sm}-\mathrm{Nd}$ model ages and $\mathrm{Rb}-\mathrm{Sr}$ isochron ages

1.17 to $0.85 \mathrm{Ga} \mathrm{Sm}-\mathrm{Nd}$ model ages for granite-gneisses with positive $\mathrm{e}_{\mathrm{Nd}}$

Granite-gneisses from the Arenópolis and Mara Rosa regions

Age of primitive magma formation

Age of primitive magma crystallization 
Table 1-continued

\begin{tabular}{ll}
\hline Reference & Geological units \\
Geochronological method & Interpretation
\end{tabular}

Results

$899 \pm 7 \mathrm{Ma}$ for the U-Pb upper intercept; lower intercept is concordant with sphene analysis (ca. $637 \mathrm{Ma}$ ) ca. $856 \mathrm{Ma}$ (U-Pb single zircon age)
Age of main metamorphic-deformational event Arenópolis, Matrinxã and Sanclerlânda granitegneisses and Jaupaci subvolvanic granite Tonalitic gneiss from Mara Rosa region

$\mathrm{V}$-Development of volcanosedimentary sequences (950 to $800 \mathrm{Ma}$ )

Pimentel (1990), Pimentel et al. (1991b), Pimentel and

Fuck (1992), Pimentel et al. (1993a,b), Viana and

Pimentel (1994)

$\mathrm{U}-\mathrm{Pb}$ multigrain fractions of zircon, $\mathrm{Sm}-\mathrm{Nd}$ model ages and $\mathrm{Rb}-\mathrm{Sr}$ isochron ages

1.37 to $0.92 \mathrm{Ga} \mathrm{Sm}-\mathrm{Nd}$ model ages for metarhyolites and metabasalts with positive $\mathrm{e}_{\mathrm{Nd}}$

$929 \pm 8 \mathrm{Ma}$ and $764 \pm 14 \mathrm{Ma}$ for the upper intercept of metarhyolites from Arenópolis and Jaupaci volcanosedymentary sequences; lower intercept is concordant with sphene analysis (ca. $600 \mathrm{Ma}$ )

$862 \pm 8 \mathrm{Ma}(\mathrm{U}-\mathrm{Pb}$ single zircon age)

Age of primitive magma formation

Arenópolis, Iporá and Jaupaci volcanosedimentary sequences associated with the calc-alkaline granitegneisses

Island-arc volcanosedimentary sequences

Age of primitive magma crystallization and main metamorphic-deformational event

Age of primitive magma crystallization for Mara Rosa metavolcanics

I-Metamorphism of low to medium grade metasedimentary sequences (Serra da Mesa)

Cassedane et al. (1972)

$\mathrm{Pb}-\mathrm{Pb}$ in galenas

$1030 \pm 70 \mathrm{Ma}$
Sulphide lenses and veinlets in a thin dolomitic layer emplaced in a calcschist quartzite sequence $\pm 10 \mathrm{~km}$ ENE of Uruaçú city (Porto Maranhão)

Age of metamorphic-deformational event

VII-Granulite facies metamorphism in the upper thermally softenned plate (800 to $650 \mathrm{Ma}$ )

Suita et al. (1994a, 1994b); Suita (1996)

$\mathrm{U}-\mathrm{Pb}$ multigrains fraction in zircon $(782 \pm 3 \mathrm{Ma}$ for the lower intercept)

$\mathrm{U}-\mathrm{Pb}$ multigrains in monazite $(785 \pm 8 \mathrm{Ma})$

$\mathrm{Pb}-\mathrm{Pb}$ in rutile $(639 \mathrm{Ma})$
Quartz diorite, granulite and amphibolites from Barro

Alto Mafic-ultramafic Complex

Cordierite-sillimanite gneiss from Juscelândia volcanosedimentary sequence

Pegmatitic gabbro from Serra da Malacacheta 
Table 1-continued.

\begin{tabular}{ll}
\hline Reference & Geological units \\
Geochronological method & Interpretation
\end{tabular}

Results

VIII-Development of peralluminous syncollisional granites (800 to $600 \mathrm{Ma}$ )

Pimentel et al. (1992)

$794 \pm 10 \mathrm{Ma}$ for the upper intercept of $\mathrm{U}-\mathrm{Pb} \quad$ Maratá Gneiss Lithodeme

multigrains fraction

ca. 2,000 Ma Sm-Nd model ages for the gneiss with Age of magma generation from crustally resident

negative $\mathrm{e}_{\mathrm{Nd}}$

material of ca. $2,000 \mathrm{Ma}$

IX-Emplacement of late-tectonic granites (650 to $500 \mathrm{Ma}$ )

Pimentel (1990); Pimentel and Fuck (1992)

$\mathrm{U}-\mathrm{Pb}$ multigrains fraction

590-485 Ma for the upper intercept

Granite intrusions (Rio Caiapó, Serra Negra and Iporá) in the Arenópolis, Iporá and Jaupaci volcano-sedimentary sequences. Alkalic granites related to late tectonic $\mathrm{K}_{2} \mathrm{O}$ rich magmas

Moura and Gaudette (1993)

Single zircon $\mathrm{Pb}$-evaporation

Granite intrusions in metasedimentary Estrondo

$655 \pm 24$ Ma for Santa Luzia Granite

Group and in transcurrent Transbrasiliano lineaments

Barradas et al. (1992)

$\mathrm{Rb}-\mathrm{Sr}$ total rock samples

$665 \pm 12$ Ma for Santa Luzia Granite

$510 \pm 15 \mathrm{Ma}$ for Matança Granite

Minimum age of magmatism

X-Development of Transbrasiliano Lineaments (650 to $500 \mathrm{Ma}$ )

Lafon et al. (1994)

$\mathrm{Pb}$-evaporation in galenas

$552+59 /-52 \mathrm{Ma}$ for the lower intercept and

$2109+74 /-80 \mathrm{Ma}$ for the upper intercept
Sulfides from gold-bearing quartz veins emplaced in the transcurrent shear zones

Ages of galena crystallization is gave by lower intercept; the upper intercept points to the $\mathrm{Pb}$ source

XI—Development of the foreland basin (780 to $550 \mathrm{Ma})$

$\mathrm{Pb}-\mathrm{Pb}$ in galena

Cassedane et al. (1972)

$786 \pm 30 \mathrm{Ma}$

Cassedane and Lasserre (1969)

$740 \pm 40 \mathrm{Ma}$
Age of sedimentation of pseudo-oolitic mineralized Bambuí Carbonates from Faz. Traíras (MG)

Age of deformation and mineralition in the Vazante Mine (Bambuí Carbonates) 
Table 1—continued.

\begin{tabular}{ll}
\hline $\begin{array}{l}\text { Reference } \\
\text { Geochronological method } \\
\text { Results }\end{array}$ & $\begin{array}{l}\text { Geological units } \\
\text { Interpretation }\end{array}$ \\
\hline $\begin{array}{l}\text { Amaral and Kawashita (1967) } \\
670 \pm 20 \mathrm{Ma} \text { for isochron age in total rock samples }\end{array}$ & $\begin{array}{l}\text { Bambui carbonates and shales near São Francisco city } \\
\text { (MG) } \\
\text { Minimum age for sedimentation } \\
\text { Age of metamorphic-deformational process in } \\
\text { Thomaz Filho and Lima (1981) } \\
560 \pm 40 \text { Ma for isochron age in thin fraction samples } \\
\text { intercalated shales and carbonates from Sete Lagoas Fm. } \\
\text { (Vazante, MG) }\end{array}$ \\
\hline
\end{tabular}

Babinski et al. (1993)

$\mathrm{Pb}-\mathrm{Pb}$ in carbonate rocks

$872 \pm 290 \mathrm{Ma}$

$686 \pm 69 \mathrm{Ma}$

$520 \pm 53 \mathrm{Ma}$

\author{
Age of sedimentation and metamorphism \\ Deformed Bambuí Carbonates \\ Undeformed Sete Lagoas Fm. carbonates; minimum \\ age of sedimentation \\ Undeformed Sete Lagoas Fm. carbonates; mobilization \\ of fluids from the older foreland basin basement through \\ faults
}

This rock intrudes the Malacacheta Sequence, the upper part of the Barro Alto layered maficultramafic complex. In the same way, Suita et al. (1994a, 1994b) have dated a garnet-cordieritebiotite-sillimanite-quartz gneiss from a tectonic sliver within the basal part of the Barro Alto Complex and found an upper intercept of $1267 \pm 9 \mathrm{Ma}$. These results agree with the divergent regime known to occur in the Amazonian plate (Dall'Agnol et al., 1987, 1994). Nevertheless the petrotectonic nature of the Juscelândia volcano-sedimentary sequence is not fully understood, its northern volcano-sedimentary sequences counterparts (Coitezeiro and Palmeirópolis), located west of the Niquelândia and Canabrava layered complexes, have petrochemical characteristics that corroborate such a divergent tectonic regime. Brod and Jost $(1989,1991)$ have shown a bimodal volcanism with alkaline affinity, as yet as alkaline granitic intrusions on the western border of the Niquelândia Layered Complex; Brod and Jost $(1989,1991)$ have also distinguished some mafic intrusive bodies in the granitic-gneissic basement of the Coitezeiro volcano-sedimentary sequence, that are chemically different from Niquelândia layered complex. Araújo (1986) found a tholeiitic chemical affinity in the basic volcanism of the Palmeirópolis volcano-sedimentary sequence and regarded its $\mathrm{Zn}-\mathrm{Cu}-\mathrm{Pb}$ deposits to belong to a mid-ocean ridge setting. The operation of a divergent regime in the upper Mesoproterozoic of the TSP seems probable.

\section{TSP Neoproterozoic structural framework}

The main tectonic feature of the TSP is a strong gravimetric anomaly (Hasui and Haralyi, 1985) clearly defined for $\pm 1700 \mathrm{~km}$ long; it is seen to juxtapose high density rocks to the west over low density metasedimentary rocks to the east, in order to develop a strong Bouguer gravity gradient 
greater than 70 mgals (Fig. 1). This linear gravimetric feature is related to an ophiolitic mélange petrotectonic association (Strieder and Nilson, 1992a), making up integral part of a large, regionally extended nappe structure (D2), named Abadiânia Nappe by Strieder and Nilson (1993a). The Abadiânia Nappe lithologies and structures may be regionally correlated and are delimitated by the Brasília Main thrust fault (the floor thrust) and the Serra Dourada breaching fault (the possible root thrust). These elements led to the definition of the Abadiannia Nappe Thrust Sheet (ANTS), a characteristic tectono-stratigraphic terrane of Central Brazil (Fig. 1 and 4). The ANTS and the linear gravimetric anomaly are interpreted as the TSP suture zone.

The ANTS internally ordered "pseudo-stratigraphy" was developed during a penetrative mylonitic episode (D1; Strieder and Nilson, 1994). The "pseudo-stratigraphic" sequence is composed by a (1) gneissified granite unit (Padre Souza Gneiss Suite), (2) gneissified subvolcanic-microgranite unit (Maratá Lithodeme), (3) differentiated mafic-ultramafic bodies granulitized prior their emplacement in the nappe structure (Brumado Gneiss Suite), and the (4) Abadiânia Supersuite (Araxá metasedimentary suite and a Tectonic Block fragments suite), which is the ophiolitic mélange.

The Araxá metasedimentary suite is made up by a transitional sequence of quartzites, muscovite quartzites, graphite-muscovite-quartz schist, garnet-mica-quartz schists, and staurolite-garnetmica-quartz schist. The tectonic block fragments were strongly deformed since D1, and do not show any pre-D1 deformational structure; then, they are believed to be tectonically emplaced in the Araxá metasedimentary Suite during D1 mylonitic event. The characteristics of the Araxá metasediments and their association with strong linear gravimetric anomalies suggest subduction trough deposits. The gneissified granites (Padre Souza Suite and Maratá Lithodeme) are peraluminous and show affinity to sin-collisional granites (Strieder, 1993b); they were also deformed from D1 deformational phase onward.

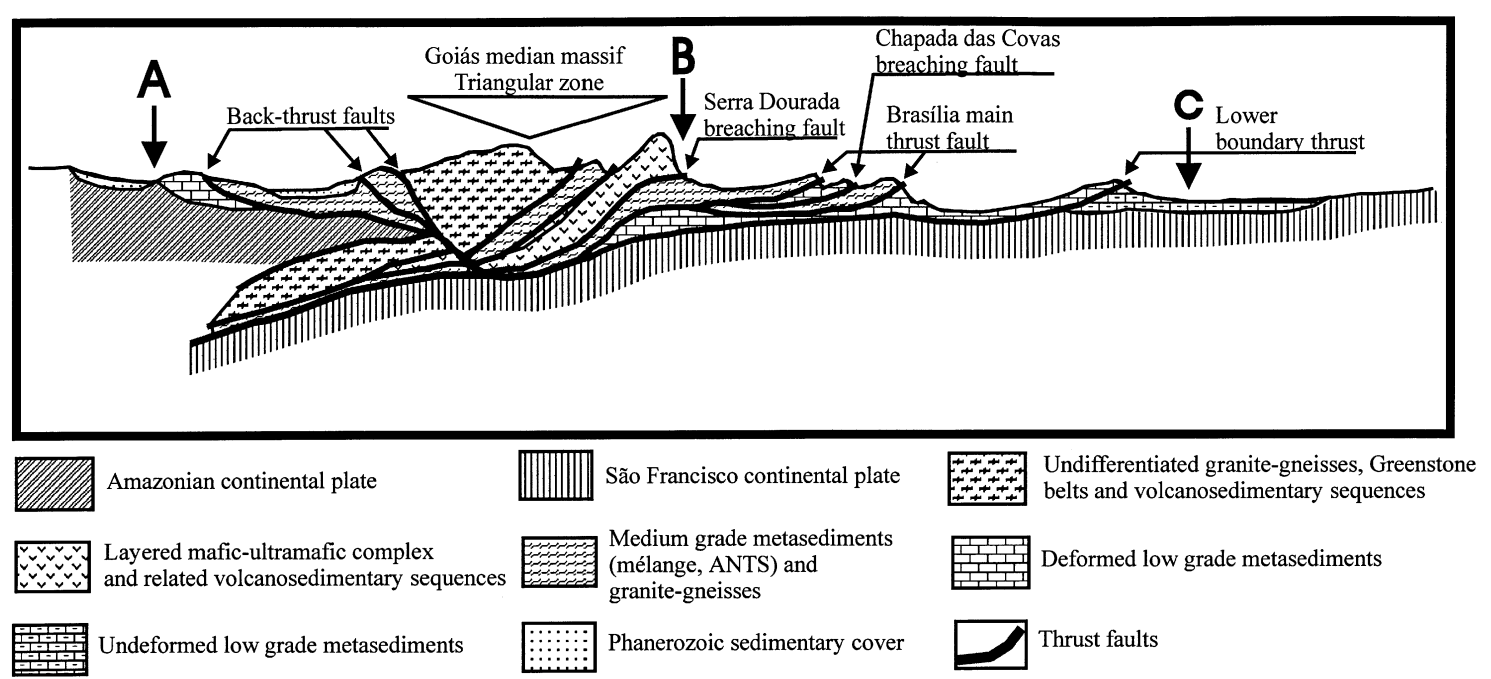

Fig. 4. Actual cross-section through the Tocantins Structural Province as indicated in Fig. 3 (A-B-C) to illustrate the main structures discussed in the text. The horizontal scale is the same as that of Fig. 3 . The vertical scale is about 4 times the horizontal scale, but some geological units and structures are exaggerated to put them in evidence. 
The Tectonic Block Fragments suite is composed by microgabbros (epidote-amphibole schists blocks), serpentinites and their Mg-rich schists in the contact aureole (serpentinite blocks) and biotite-muscovite-carbonate schist (marble blocks). The serpentinite blocks are less than $5.0 \mathrm{~km}$ long and are invariably metasomatized at their contacts with the country Araxá metasediments (Strieder and Nilson, 1992b); they have lens-like pods ( $2.0 \mathrm{~m}$ long, $0.5 \mathrm{~m}$ thick) of typical Al-rich podiform chromitite (Strieder and Nilson, 1992c). The epidote-amphibole schist blocks are larger $(<10-12 \mathrm{~km}$ long) and preserve some deformational pods, where the original texture may be recognised (Strieder and Nilson, 1992d). The marble blocks were interpreted, based on their discrepant sedimentary characteristics, as exotic fragments (Strieder, 1989, 1993b; Strieder and Nilson, 1992a). Further examination recognised structural and sedimentary features that enable their correlation with the lower Paranoá metasediments thrust sheet (Roscoe and Araújo Filho, 1994).

The geometry of tectonic structures important for elucidating the TSP evolution was detected in the lineament analysis of LANDSAT images (Strieder, 1993b; Strieder and Nilson, 1993b). Besides the thrust surfaces, structural lineament inflections were identified (Fig. 2) and they are useful as kinematic indicators of thrust sheet displacement direction, as well as to quantify the thrust displacement itself (Coward and Potts, 1983). The structural inflections show the same displacement direction (S70-80E), which is at high angles to the main thrust faults and suture zone linear gravimetric anomaly. The collisional process, then, must had been of frontal type, instead of oblique as suggested by Hasui and Haralyi (1985). These structural features do not favor suggested crustal block thrusting and rotation.

The largest structural inflection lies along the $15^{\circ} 30^{\prime} \mathrm{S}$ parallel, west of Brasília, is named Pirineus Megainflection (PMI) and extend for at least $250 \mathrm{~km}$ (Strieder, 1993b). Around the western edge of Brasília, the ANTS is eroded in the Brasília Tectonic Syntaxis (Strieder and Nilson, 1993b), which shows $90 \mathrm{~km}$ of minimum displacement of ANTS over the lower Paranoá metasediments thrust sheet (Fig. 1). The PMI differential movement is accommodated by a series of transcurrent faults that crosscut the recumbent fold forming the ANTS. In the north side, the transcurrent faults are WSW oriented and show dextral movements, while the southern transcurrent faults are ESE oriented and have a sinistral sense of movement (Strieder, 1990, 1993b). The PMI is associated with a large re-entrance of linear gravimetric anomaly of the suture. The surficial structural record for this re-entrance is just observed in the ANTS (PMI) and in the upper thrust sheets, as one can see in the south border of Barro Alto layered mafic-ultramafic complex. This means that the linear gravimetric anomaly reentrance is a feature superposed on the upper thermally softened crustal plate and, then, has been interpreted as a result of a rigid wedge indenter related to the border of the underthrusting São Francisco plate (Strieder and Nilson, 1992a).

The lineament analysis has shown some breaching faults in the central part of Brasilia Subprovince (Strieder and Nilson, 1993a, 1993b). For example, the Chapada das Covas breaching fault (Strieder, 1993b) cut across both the lower Paranoá metasediments thrust sheet and upper ANTS dividing them into two blocks (Fig. 3); the western block is thrusted over the eastern (Fig. 4). Strieder (1993b) attributed the onset of the Chapada das Covas breaching fault to the wedge indentation of the underthrusting São Francisco plate. Another possible breaching fault may be the Serra Dourada thrust (Fig. 3). It is located to the west and delimitates the ANTS exposure. At Serra Dourada, the recumbent fold on Araxá metasediments is deformed into an open synformal fold at the footwall of the thrust fault (Strieder, 1993b; Strieder and Nilson, 1993a, 1993b). The 
upper thrust sheet at Serra Dourada consists of tonalitic gneisses of the Goiás Greenstone Belt (Fig. 4).

Toward the south, the linear gravimetric anomaly is continuous and contours the Cunha de Guaxupé (Hasui et al., 1990). The ESE inflection of the linear gravimetric anomaly in the Cunha de Guaxupé is related to the Serra da Canastra Inflection. The Serra da Canastra inflection is a narrow tectonic syntaxis (Strieder and Nilson, 1993b) and its lineaments show physical continuation toward the north margin of Cunha de Guaxupé. This means that some lithotectonic units of the ANTS may be correlated with those occurring in the Cunha de Guaxupé, such as São João del Rei and Andrelândia metasediments. Roig and Schrank (1992) interpreted the Andrelândia metasediments as an ophiolitic melange, which is in good accordance with the results obtained by Strieder and Nilson (1992a) for Araxá metasediments.

The Cunha de Guaxupé lithotectonic units are thrust toward the east (Vasconcellos, 1988) and this is verified by the linear gravimetric gradient of the suture zone. Thus, the Cunha de Guaxupé is regarded as a tectonic wedge connected to the upper thermally softened continental crust undergoing overthrusting. Nevertheless the Cunha de Guaxupé is not a rigid indenter, its lateral limbs show transcurrent faults superposed on the thrust faults (Wernick et al., 1979; Hasui et al., 1990; Ebert et al., 1993). These faults accommodate the final stages differential movements on the Cunha de Guaxupé. The overthrust of a thermally softened continental wedge give rise to a tectonic antitaxis (Strieder and Nilson, 1992a), since its configuration is opposed to that developed at PMI.

\section{Geochronological constraints on the TSP Brasiliano Orogenic Cycle}

The kinematic evolution of the TSP can be described into stages constrained by recent geochronological and structural data (Fig. 5). The oldest Neoproterozoic age clearly related to the Brasiliano Orogenic Cycle in the TSP was obtained by Pimentel et al. (1991b) and by Pimentel and Fuck (1992) in the Bom Jardim de Goiás region (western Goiás). They dated a granite-gneiss unit through $\mathrm{U}-\mathrm{Pb}$ and $\mathrm{Sm}-\mathrm{Nd}$ methods and found ages of ca. 940-895 Ma for its mantle derivation. The associated volcano-sedimentary sequences were also dated at ca. 930-760 Ma. The composition of these units display chemical affinity with juvenile magmatic arcs; the granitegneisses are calc-alkaline rocks (I-type) and the volcanics vary from low- $\mathrm{K}_{2} \mathrm{O}$ basalts to high- $\mathrm{K}_{2} \mathrm{O}$ rhyolites (Pimentel and Fuck, 1992). In reality, this finding was the first record of ensimatic magmatism conclusively related to the Neoproterozoic evolution of the TSP (Pimentel and Fuck, 1992).

To the north, the Mara Rosa volcano-sedimentary sequence and its plutonic counterparts were once correlated with the Pilar de Goiás greenstone belt sequence (Danni and Ribeiro, 1978). However, recent precise geochronological data has revealed their Neoproterozoic origin (Pimentel et al., 1993a, 1993b; Viana and Pimentel, 1994). The geochemical features of the volcanic (Kuyumjian, 1989) and plutonic rocks (Viana and Pimentel, 1994) were regarded to calc-akaline magmas of island-arc tectonic settings. The $\mathrm{Sm}-\mathrm{Nd}$ isotopic ratios confirm the island-arc setting, because the positive eNd indicates primitive magmas (Viana and Pimentel, 1994). The tonalitic gneisses in the Mara Rosa region were dated $856 \mathrm{Ma}$, while the metavolcanic rocks gave an age of $862 \pm 8 \mathrm{Ma}$ (U-Pb single zircon method, Pimentel et al., 1993a, 1993b, Table 1). The model age obtained for the tonalitic gneisses, metavolcanics and intrusive subvolcanic rocks is 1.0 Ga (Viana and Pimentel, 

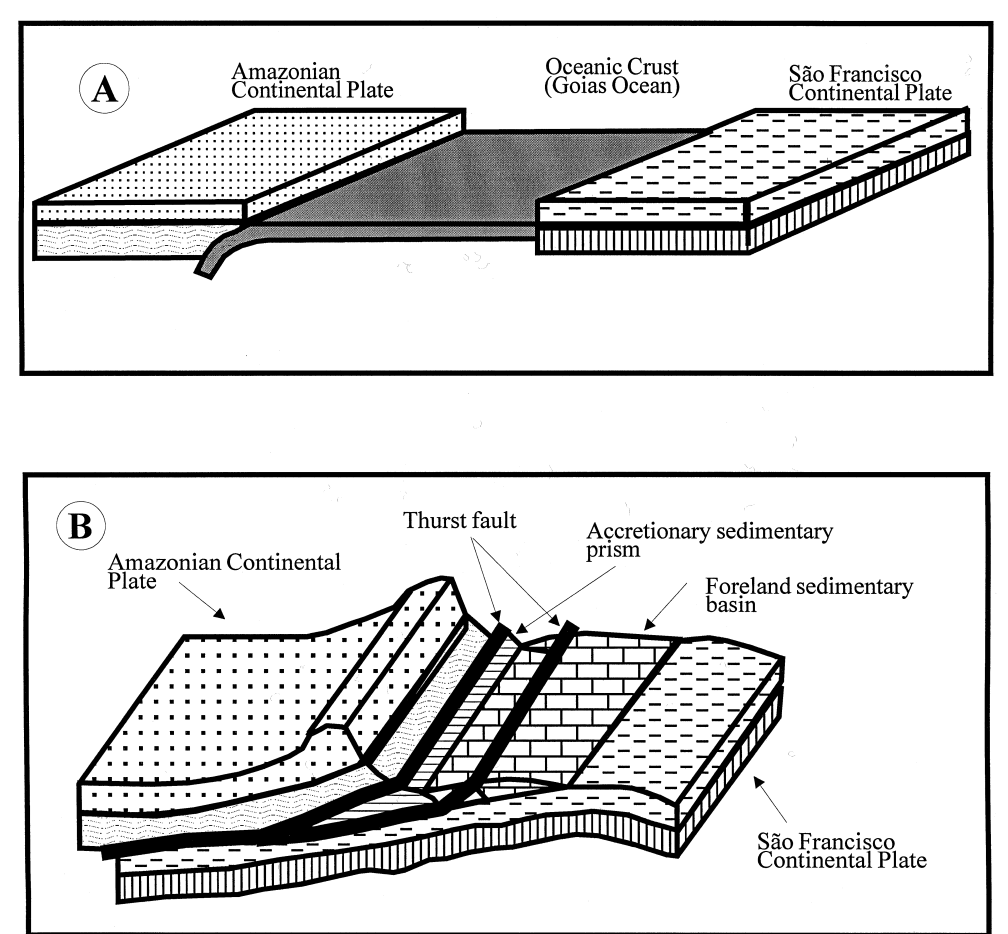

Fig. 5. Kinematic evolution of the Tocantins Structural Province (TSP). The sequence of block diagrams shows the tectonic stages and structures discussed in the text. See text for additional discussion. (A) Initial conditions of Goiás Ocean subduction. (B) Initial collisional structure of the Amazonian and São Francisco continental plates.

1994). These data confirm the existence of a Neoproterozoic ocean in Central Brazil during the Neoproterozoic [Fig. 5(a)] and seem, to date, to constrain the beginning of the subduction process to ca. $940 \mathrm{Ma}$ (Table 1).

The final closure of the intervening ocean between the Amazonian and São Francisco continental crusts, however, was not yet well constrained [Fig. 5(b)]. Pimentel et al. (1992) dated the Maratá Lithodeme as $794 \pm 10 \mathrm{Ma}$; since this peraluminous gneissic granite is deformed from the ANTS organization onward, it seems to indicate that the continental collision in the TSP took place around $800 \mathrm{Ma}$. The time span between the onset of subduction and the continental collision may seem to be large. But, the $800 \mathrm{Ma}$ for the continental collision agrees with the expected time of the indentation process at PMI (Strieder, 1993b) and the granulite facies metamorphism of the great mafic-ultramafic layered complexes in Central Goiás (790-770 Ma: Ferreira Filho et al., 1994; Suita et al., 1994a, 1994b).

Considering the $800 \mathrm{Ma}$ continental collision in the TSP, it is interesting to observe that I-type to A-type granitic intrusions that intrude earlier Neoproterozoic granite-gneisses (ca. 950-895 Ma, Pimentel and Fuck, 1992) are younger than Maratá Lithodeme; their age spread from 650 Ma to $550 \mathrm{Ma}$ (Table 1). These granitic intrusions are also located in the older overthrust terranes that separate the Paraguai-Araguaia and Brasília subprovinces (Goiás median massif) and have been interpreted as late- to post-tectonic ones (Pimentel and Fuck, 1992). Some of these intrusions are 

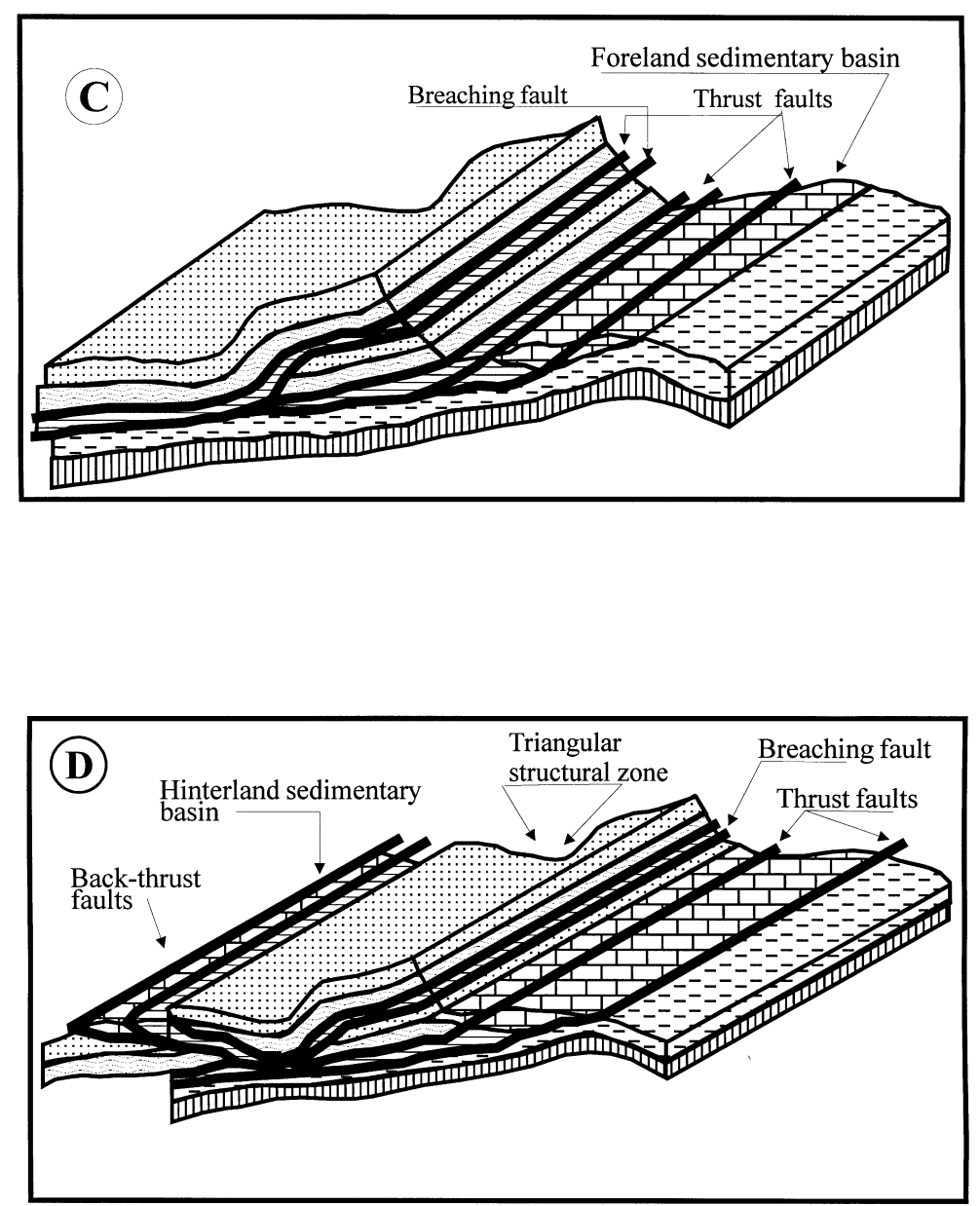

Fig. 5 continued. (C) Collisional duplication of the Amazonian plate by breaching faults; this stage was developed during the final penetration of the rigid indenter of the São Francisco plate and amplified the flexural movements in the foreland sedimentary basin. (D) Final collisional structure of the TSP; the back-thrust faults cut off the transcurrent faults of Transbrasiliano lineaments and amplified vertical movements on the hinterland sedimentary basin.

related to large transcurrent faults developed as consequence of indentation process in the PMI (Gottardo, 1996).

During the collisional stage, a shallow water sedimentary basin developed just over the linear gravimetric low (Fig. 1). It is mainly composed by quartzites, pelites, and platformal carbonates with algal mats and stromatolites. These sedimentary rocks were deformed during thrusting and metamorphosed to a low grade facies (Fig. 4). The thrust displacement is directed toward the ESE and decreases in intensity in the same direction, so that one can yet find undeformed horizontal strata covering the older São Francisco plate geological units away from the suture zone. This sedimentary basin and its geological units were interpreted as a foreland basin (Kiang et al., 1988), or as a foreland fold and thrust belt (Pimentel et al., 1992). The $\mathrm{Pb}-\mathrm{Pb}$ ages from the carbonate 
unit galena's (Amaral, 1968; Cassedane et al., 1972; Babinski et al., 1993) and Rb/Sr from pelite units (Amaral and Kawashita, 1967; Thomaz Filho and Lima, 1981) spread from ca. 780 Ma to ca. $550 \mathrm{Ma}$ (Table 1). The age data range for the foreland basin seems to constrain its onset to the closure of the intervening ocean and the beginning continental collision at the TSP (ca. $794 \mathrm{Ma}$. for Maratá Lithodeme). The age span for the foreland basin development is also indicated by the late- to post-tectonic granitic intrusions into the overriding plate (Table 1). The geochronological data also indicate that sedimentational and deformational episodes took place in the same time span in this foreland sedimentary basin.

\section{Integrated discussion on the TSP tectonic evolution}

The details of geological, petrochemical and geochronological data on the TSP lithotectonic units is rapidly increasing. However, there are some important gaps, specially relating to structural information. Much has been written about local geological units in the TSP and the importance of the Brasiliano Tectonic Cycle in the structural reorganization of older lithotectonic terranes has increased. Thus, it seems appropriate to present an overall tectonic framework of the TSP.

The main question regarded to the onset of the Brasiliano Tectonic Cycle concerns to the age of the opening of the Goiás Ocean. The most voluminous data that indicate an extensional regime in Central Brazil have been obtained from the large mafic-ultramafic complexes and granites and rhyolites of anorogenic-type dated as ca. $1700 \mathrm{Ma}$ (Pimentel et al., 1991a; Suita et al., 1994a, 1994b). However, due to the scarcity of geochronologic data indicative of metamorphic-deformational episodes in the time span between 1700 and $1000 \mathrm{Ma}$, and due to the improbable existence of the ocean over such a long time, it seems that, at least in this part of the older continental crust, the $1700 \mathrm{Ma}$ anorogenic episode did not culminate in ocean opening.

The 1280-1267 Ma ages obtained for a pegmatitic hornblende grabbro in the Barro Alto Layered Mafic-ultramafic Complex and for a garnet-cordierite-biotite-sillimanite-quartz gneiss slivers in the Juscelândia Volcanosedimentary Sequence (Suita et al., 1994a, 1994b) seem to point to a younger extensional episode, as recorded by the petrochemical features of the others volcanosedimentary sequences (Araújo, 1986; Brod and Jost, 1989, 1991). More data are clearly needed, but the present results help in selecting the adequate lithological units in order to solve the problem. To date, it seems adequate to characterize an upper Mesoproterozoic magmatic event during an extensional regime, that culminate with the opening of the Goiás Ocean in the TSP. The present geochronological data, then, show a time span of 250-300 Ma from the onset of ocean opening to the first records of ocean subduction. The $1000 \mathrm{Ma}$ age for the beginning of the subduction in the TSP, therefore, must be taken as a minimum, since the complete ocean consumption and longlived collisional episode may have obliterated a part of the geological records.

The recent geochronological, structural and geochemical data regarded to the Neoproterozoic show that the Brasiliano Orogenic Cycle must be understood in a different way. The recognized ensimatic units (Pimentel and Fuck, 1992; Viana and Pimentel, 1994) put an end point in the purely ensialic assumptions for the development of the TSP. At the same time, the model ages for the Maratá Lithodeme $(749 \pm 10$ Ma magmatism derived from $2.0 \mathrm{Ga}$ crustal material, Pimentel et al., 1992) and its syncollisional peraluminous affiliation (Strieder, 1993b), and granulite metamorphism of the mafic-ultramafic complexes (Suita et al., 1994a, 1994b) point to an important 
collisional episode in the TSP. The dismembered ophiolitic blocks in the Araxá metasediments represent arc-derived units (Strieder and Nilson, 1992a; Strieder et al., 1994). The Araxá meta-sediments are then better regarded as accretionary prism, than a passive margin sedimentary sequence as interpreted by Hasui et al. (1994).

Thus, it is possible to distinguish two major tectonic phases in the TSP: 1) the first one is characterized by island-arc amalgamation with the western Amazonian plate (950-800 Ma) [Fig. 5(a)], and 2) the second is characterized by continental lithospheric juxtaposition (800-600 Ma) [Fig. 5(b)]. The Brasiliano Tectonic Cycle in Central Brazil may be constrained to the 950-600 Ma time span and, in this way, it is not Grenville $(1.3-1.0 \mathrm{Ga})$; to date, it is possible that, during the Grenville Orogenic Cycle, the TSP was subject to rifting episodes (Suita, 1996).

It must be remembered, however, that the geochronological data are still scarce to allow a clear tectonic picture of the convergence. The geochronological data, to date, are from specific geological units at specific localities. The regional correlations are constrained, because the thrust surfaces are not yet well-defined, neither the restoration of thrust displacements have been tried. It is, therefore, hard to propose a tectonic evolution based on temporal and areal parameters. Taking into account the geometry of the Amazonian and São Francisco plates borders in the TSP frontal convergence, some degree of tectonic differentiation may be envisaged. It means that one may find different ages for island-arc amalgamation and continental collision at different parts of the TSP. It will be important to refer future geochronological data to a clear structural framework in order to interpret these data in space and time.

An attempt to define the structural framework of the TSP was presented by Strieder (1993b) and Strieder and Nilson (1993b), yet this work is still in progress. The preliminary results presented by Strieder and Nilson (1993b) are focused on the south part of the Brasilia Subprovince, and show the location of the thrust faults. Three important features were distinguished: 1) the differential thrust displacement structures, 2) the lowermost boundary thrust (LBT), and 3) the breaching faults. The differential thrust displacement structures indicated the frontal collisional process (Fig. 2). The LBT makes possible to put apart the autochthonous from the para-autochthonous to alochthonous zones (Figs. 1 and 3). The breaching faults, on the other hand, introduce a tectonic component not well understood at this moment: the duplication of the former thrust sheet (Fig. 4). To date, it is not clearly known which of the thrusts identified by Strieder and Nilson (1993b) are of breaching type and which are not, since there is no detailed work on thrust surfaces. Similarly, there has not been an attempt to restore thrust displacements and to correlate the geological units in each thrust sheet.

The identification of the Chapada das Covas breaching fault (CCBF) has been mainly based on the Paranoá metasediments thrust over the ANTS (Figs. 3 and 4). The development of this breaching fault is related with the indentation of the São Francisco rigid wedge in the PMI (Strieder, 1993b). Toward the west, the Serra Dourada breaching fault (SDBF) juxtaposed the Goiás Greenstone Belt units over the ANTS (Strieder and Nilson, 1993b). Since the SDBF truncates the ANTS recumbent fold $\left(\mathrm{F}_{2}\right)$, and since similar geological units (Serra da Mesa and EstrondoAraguaia metasediments) are present to the northwest over the greenstone belt units, it may be possible that some others large breaching faults will be discovered (Figs. 3 and 4).

The main clue on TSP breaching faults is provided by the juxtaposition of different geological units in the "Goiás median massif" separating the Brasília from Paraguai-Araguaia subprovinces. The structure of "Goiás median massif" plays an important role in the tectonic framework of the 
TSP. It has been suggested that its structure near the PMI was formed as a result of the trapping of small continental plates or magmatic arcs during the convergence of the large continental plates such as the Amazonian and São Francisco (Strieder and Nilson, 1992a). Fuck (1994) has followed this interpretation, regarding the "Goiás median massif" as a microcontinent trapped between the main plates. Costa et al. (1987) suggested a crustal-scale pop-up resulting from an oblique collision during the Late Archean. Later, Hasui et al. (1994) suggested Lower Proterozoic frontal collisions directed westward (Paraguai-Araguaia Subprovince) and eastward (Brasília Subprovince). Both these interpretations consider the "Goiás median massif" as a kind of microcontinent.

It is nowadays realized that a microcontinent must be rimmed by thrust surfaces with ophiolitic mélange, and by gravity anomalies. In the "Goiás median massif", however, the gravity anomaly is clearly present at its eastern border. Despite the scarcity of gravity measurements on the western Paraguai-Araguaia subprovince, one can see a slowly decreasing followed by a slowly increasing Bouguer gravimetric gradient westward (Hasui and Haralyi, 1985). The gravity structure of the western Paraguai-Araguaia subprovince is different from the Eastern Brasília subprovince and its ophiolitic mélange (ANTS). The gravity structure of the western Paraguai-Araguaia subprovince does not support the interpretation of a suture zone.

Studies still in progress by Cunha (1996) and Gottardo (1996) reveal that transcurrent Transbrasiliano lineaments (Schobbenhaus Filho et al., 1975) result from the indentation process at PMI, and that these lineaments and Neoproterozoic granitic plutons are affected by low angle reverse cleavages and faults directed toward the west. These reverse faults convert several geological units into slices and are interpreted as back-thrusts of the Brasiliano Orogenic Cycle in the TSP (Cunha, 1996; Gottardo, 1996; Strieder et al., 1997).

The structure of the "Goiás median massif", on the other hand, may be seen as a triangular zone developed by the juxtaposition of different geological units through thrusting and breaching faults directed toward ESE [Fig. 5(c)] and through back thrusts directed westward [Fig. 5(d)]. Thus, the "Goiás median massif" is not a microcontinent, but a collage of Archean greenstone belts and granite-gneisses, Meso and Neoproterozoic volcanosedimentary units, as well as granitegneisses and mafic-ultramafic complexes. The collage was mainly produced by thrusting during the island-arc amalgamation stage, and by thrusting and breaching during the continental collision stage. The thrusting and breaching during the continental collision certainly lead to the construction of a high Neoproterozoic orogenic cordillera positioned in the "Goiás median massif".

Following the continental collision, the indentation process in the PMI developed large transcurrent faults in the upper thermally softened plate (Strieder et al., 1994). These transcurrent faults were named Transbrasiliano lineaments (Schobbenhaus Filho et al., 1975). The onset of such transcurrent faults generated space for the emplacement of calc-alkaline to alkalic type granites, as well as the gold-bearing quartz veins in the shear zones (Gottardo, 1996). The time span of granite emplacement in the transcurrent shear zone is between $760 \mathrm{Ma}$ and $550 \mathrm{Ma}$ (Table 1).

Following the continental collision, there was also the development of a foreland basin over the downgoing São Francisco plate. The deposition of a series of metasedimentary units, such as Paranoá, Paracatu and Bambuí, are connected with the migration of the basinal depocenter and thrusting in its inner part. On the other hand, the time span recorded for the foreland development (Table 1) is similar to that recorded for the transcurrent shear granitic plutons (760-500 Ma). This points to a synchronous development during the convergence of the continental plates.

The pilling up order of the foreland basin sediments do not yet consider the thrust effects in 
inverting stratigraphic sequences, since no stratigraphic restoration have been tried. Some results are available concerning the basement of the foreland basin. High resolution seismic profiling conducted by PETROBRÁS (Teixeira et al., 1993) showed that the downgoing São Francisco plate displays rift-like structures infilled with coarse sediments. This feature may be interpreted as the results of the flexural rigidity of the downgoing plate, instead of the evolution in a passive rifted margin of the São Francisco plate as interpreted by Dominguez (1993); Braun et al. (1993) and Martins et al. (1993). Considering the high displacements measured for the thrust faults ( $250 \mathrm{~km}$, Strieder and Nilson, 1993b), the rifted São Francisco margin must have been subducted and its structures destroyed during the convergent deformation.

The foreland basin may also be divided into two segments according the results obtained from the lineaments' studies of Strieder and Nilson (1993b). The identification of the Lower Boundary Thrust (LBT) does permit to distinguish the 1) autochthonous zone and the 2) para-autochthonous to alochthonous zone. The first one is made up by nearly horizontal low grade to non metamorphosed strata. The second one, on the other hand, is made up by deformed and low grade metamorphosed strata. The intensity of metamorphism, deformation and thrust displacement decreases eastward.

\section{Acknowledgements}

The authors thank Prof. João Felipe C.L. da Costa (DEMIN-UFRGS), Prof. Farid Chemale Jr. and Prof. Léo A. Hartmann (IG-UFRGS) for revision and comments about the text. The authors thank the referees for improving this paper. We also thank to Doctoral Candidate, Evandro Gottardo, for helping with figures. AJS thanks to Brazilian Research Council (CNPq) for research grant.

\section{References}

Almeida, F.F.M., 1967. Origem e evolução da plataforma brasileira. In: Div, Geol. Mineral. (DNPM), Rio de Janeiro (RJ), Boletim No 241, 36 p., 1 mapa.

Almeida, F.F.M., 1968. Evolução tectônica do centro-oeste brasileiro no Proterozóico Superior. An. Acad. Bras. Ciências 40, 285-295 supl.

Almeida, F.F.M., Hasui, Y., Brito Neves, B.B., 1976. The upper precambrian os South America. Boletim do Instituto de Geociências (USP), São Paulo (SP), Vol. 7, 45-80.

Almeida, F.F M., Hasui, Y., Brito Neves, B.B., Fuck, R.A., 1977. Províncias estruturais Brasileiras. In: Simpósio Geologia Nordeste, Campina Grande (PB), SBG/NE, Ata., pp. 363-391.

Almeida, F.F.M., Hasui, Y., Davino, A., Haralyi, N.L.E., 1980. Informações geofísicas sobre o oeste mineiro e seu significado geotectônico. An. Acad. Bras. Ciências 52 (1), 49-60.

Almeida, F.F.M., Hasui, Y., Brito Neves, B.B., Fuck, R.A., 1981. Brazilian structural provinces: an introduction. Earth Sci. Rev. 17 (1-2), 1-29.

Amaral, G., 1968. Resultados preliminares do estudo sobre a mineralização e composição isotópica em galenas de depósitos encaixados no Grupo Bambui. In: Congr. Bras. Geol., Vol. 20, Belo Horizonte (MG), SBG/MG, Res. Comnicações, pp. 51-53

Amaral, G., Kawashita, K., 1967. Determinação da idade do Grupo Bambui pelo método Rb/Sr. In: Congr. Bras. Geol., Vol. 19, Curitiba (PR), SBG/PR, Anais..., pp. 214-217. 
Araújo, S.M., 1986. Petrologia e mineralizações sulfetadas da Seqüência Vulcano-sedimentar de Palmeirópolis (Goiás). Dissertação de Mestrado, DEGeo-IE-UnB, Brasília (DF), 196 p. (inédito).

Babinski, M., Van Schmus, W.R., Chemale Jr., F., Kawashita, K., 1993. Evolução geológica da porção Sul da Bacia do São Francisco baseada na geoquímica isotópica de $\mathrm{Pb}$ em rochas carbonáticas. In: Simp. sobre o Cráton do São Francisco, 2, Salvador (BA), SBG/BA, 1993, Salvador (BA), Anais..., pp. 182-185.

Barradas, J.A., Lafon, J.M., Kotschoubey, B., 1992. Geocronologia $\mathrm{Pb}-\mathrm{Pb}$ e $\mathrm{Rb}-\mathrm{Sr}$ da região de Monte do CarmoPorto Nacional (TO): novos resultados. In: Congresso Brasileiro de Geologia, 37, São Paulo (SP), SBG/SP, Anais..., Vol. 2, pp. 182-183.

Braun, O.P.G., Martins, M., Oliveira, W.J. de, 1993. Continuidade das seqüencias rifeanas sob a Bacia do São Francisco constatada por levantamentos geofísicos em Minas Gerais. In: Simp. sobre o Cráton do São Francisco, 2, Salvador (BA), SBG/BA e SGM/BA, Anais..., pp. 164-166.

Brito Neves, B.B., Cordani, U.G., 1991. Tectonic evolution of South America during Late Proterozoic. Precambrian Res. 53, 23-40.

Brod, J.A., Jost, H., 1989. Geoquímica das rochas da porção oeste do Complexo de Niquelândia e seu significado geotectônico. Geochim. Brasiliensis 1, 56-72.

Brod, J.A., Jost, H., 1991. Características estruturais, litológicas e magmáticas da Zona de Cisalhamento Dúctil do Rio Traíras, Bloco do Complexo de Niquelândia. Goiás. Rev. Bras. de Geoc. 21 (3), 205-217.

Cassedane, J., Lasserre, M., 1969. Análises isotópicas pelo método do chumbo de algumas galenas brasileiras: descrição do método utilizado. Mineração e Metalurgia 293, 215-224.

Cassedane, J., Duthou, J.L., Lasserre, M., 1972. Análises isotópicas pelo método do Chumbo de uma terceira série de galenas brasileiras. Min. Metal., Rio de Janeiro (RJ), 335, pp. 12-19.

Cordani, U.G., Brito Neves, B.B., 1982. The geologic evolution of South America during the Archean and Early Proterozoic. Rev. Bras. Geoc. 12 (1/3), 78-88.

Costa, J.B.S., Hasui, Y., Haralyi, N.L.E., 1987. The Central Brazil pop-up: an example of double ancient oblique collision. In: Conference on Deformation and Plate Tectonics, Gijón (Spaña), 1987, Universidad de Oviedo, Abstracts..., pp. 24-25.

Coward, M.P., Potts, G.J., 1983. Complex strain patterns developed at the frontal and lateral tips to shear zones and thrust zones. J. Struct. Geol. 5, 383-399.

da Cunha, F.S.S., 1996. Análise geométrica e estatística de lineamentos aplicada à pesquisa mineral: o caso da região de Porto Nacional (TO). Dissert. de Mestrado (PPGEMM-EE-UFRGS), Porto Alegre (RS), 173 p.

Dall'Agnol, R., Bettencourt, J.S., Jorge-João, X.S., Medeiros, H., Costi, H.T., Macambira, M.J.B., 1987. Granitogenesis in northern Brazilian region: a review. Rev. Bras. Geoc. 17 (4), 382-403.

Dall'Agnol, R., Lafon, J.M., Macambira, M.J.B., 1994. Proterozoic anorogenic magmatism in the Central Amazonian Province, Amazonian Craton: geochronological, petrological and geochemical aspects. Miner. and Petrol. 50, 113138.

Danni, J.C.M., Ribeiro, C C., 1978. Caracterização estratigráfica da seqüência vulcano-sedimentar de Pilar de Goiás e de Guarinos, Goiás. In: Congr. Bras. de Geologia, 30, Recife (PE), SBG/NE, Anais..., Vol. 2, pp. 582-589.

Danni, J.C.M., Fuck, R.A., Leonardos, O.H., 1982. Archean and lower proterozoic units in central Brazil. Geol. Rundsch. 71 (1), 291-317.

Dominguez, J.M.L., 1993. As coberturas do Cráton do São Francisco: uma abordagem do ponto de vista de análise de bacias. In: Dominguez, J.M.L. and Misi, A. (Eds.), 1992. O Cráton do São Francisco, Reunião Preparatória do $2^{\circ}$ Simp. sobre o Cráton do São Francisco, SBG/BA, Salvador (BA), pp. 137-159.

Ebert, H.D., Hasui, Y., Sartorato, G., Almeida, S.H., Costa, J.B.S., 1993. Arcabouço estrutural e tectônica transpressiva das faixas móveis da borda sul e sudeste do Cráton do São Francisco e da Sintaxe de Guaxupé. In: Simp. Nac. de Estudos Tectônicos, 4, Belo Horizonte (MG), SBG/MG, Anais..., pp. 166-171.

Ferreira Filho, C.F., Kamo, S.L., Fuck, R.A., Krough, T.E., Naldrett, A.J., 1994. Zircon and rutile U-Pb geochronology of the Niquelândia layered mafic-ultramafic intrusion (Brazil): constrains for the timing of the magmatism and highgrade metamorphism. Precambrian Res. 68, 241-255.

Fuck, R.A., 1994. A Faixa Brasília e a compartimentação tectônica na Província Tocantins. In: Simp. Geol. Centrooeste, 4, Brasília (DF), SBG/CO-BS, Anais..., pp. 184-187.

Gottardo, E., 1996. Alojamento de granitos em zonas de cisalhamento e sua relação com depósitos auríferos de veios: região de Porto Nacional (TO). Dissert. de Mestrado (PPGEMM-EE-UFRGS), Porto Alegre (RS), 223 p. 
Haralyi, N.L.E., Hasui, Y., 1981. Anomalias gravimétricas e estruturas maiores do Sul de Goiás. In: Simp. Geol. do Centro-oeste, Goiânia (GO), SBG/CO, Ata...., pp. 73-92.

Haralyi, N.L.E., Hasui, Y., 1982. The gravimetric information and the archean-proterozoic structural framework of eastern Brazil. Rev. Bras. Geoc. 12 (1/3), 160-166.

Hasui, Y., Almeida, F.F.M., 1970. Geocronologia do centro-oeste Brasileiro. Bol. Soc. Bras. de Geologia 19 (1), $5-26$.

Hasui, Y., Haralyi, N.L.E., 1985. A mega-estruturação de Goiás. In: Simp. Geol. Centro-oeste, II, SBG/CO-BS, Goiânia (GO), Ata...., pp. 120-144.

Hasui, Y., Costa, J.B.S., 1990. O Cinturão Araguaia: um novo enfoque estrutural-estratigráfico. In: Congr. Bras. Geologia, 36, Natal (RN), SBG/NE, Anais..., Vol. 5, pp. 2535-2549.

Hasui, Y., Costa, J.B.S., Ebert, H.D., 1990. Estruturação da extremidade oriental da chamada Cunha Guaxupé: dados preliminares. In: Congr. Bras. Geologia, 36, Natal (RN), SBG/NE, Anais..., Vol. 5, pp. 2296-2308.

Hasui, Y., Costa, J.B.S., Haralyi, N.L.E., 1994. Estrutura em quilha Brasil Central: uma feição fundamental na geologia de Goiás e Tocantins. Geociências (USP), São Paulo (SP), Vol. 13, pp. 463-497.

Kiang, C.H., Miranda, F.P., Magalhães, L., Alkimin, F.F., 1988. Considerações sobre a evolução tectônica da Bacia do São Francisco. In: Congr. Bras. de Geologia, 35, Belém (PA), SBG/NO, Anais..., Vol. 5, pp. 2076-2090.

Kuyumjian, R.M., 1989. Geoquímica e o significado do posicionamento geotectônico das rochas plutônicas da região de Chapada, Goiás, Brasil. In: Congr. Bras. Geoquímica, 2, Rio de Janeiro (RJ), SBGq, Anais..., pp. 195-201.

Lafon, J.M., Kotschoubey, B., Barradas, J.A.S., 1994. Rb-Sr and $\mathrm{Pb}-\mathrm{Pb}$ dating of the proterozoic igneous rocks and associated gold mineralization in the Monte do Carmo region, state of Tocantins, Brazil. In: Ages and Isotopes of South American Ores Symposium, IGCP, Project 342, Chile, 5 p.

Lesquer, A., Almeida, F.F.M., Davino, A., Lachaud, J.C., Maillard, P., 1981. Signification structurale des anomalies gravimétriques de la partie Sud du Craton de São Francisco (Brésil). Tectonophysics 76, 273-293.

Marini, O.J., Fuck, R.A., Danni, J.C.M., Dardenne, M.A., Loguércio, S.O.C., Ramalho, R., 1984. As faixas de dobramentos Brasília, Uruaçú e Paraguai-Araguaia e o Maciço Mediano de Goiás. In: Schobbenhaus, C., Campos, D.A., Derze, G.R., Asmus, H.E. coords., Geologia do Brasil, Public. Esp. DNPM, p. 501, 1 Mapa Geol. 1:2.500.000.

Marini, O.J., Botelho, N.F., 1986. A província de granitos estaníferos de Goiás. Rev. Bras. Geoc. 16 (1), $119-131$.

Martins, M., Teixeira, L.B., Braun, O.P.G., 1993. Considerações sobre a estratigrafia da Bacia do São Francisco com base em dados de subsuperfície. In: Simp. sobre o Cráton do São Francisco, 2, Salvador (BA), SBG/BA e SGM/BA, Anais..., pp. 167-169.

Moura, C.A.V., Gaudette, H.E., 1993. Evidence of Brasiliano/Panafrican deformation in the Araguaia Belt: implication for Gondwana Evolution. Rev. Bras. Geoc. 23 (2), 117-123.

Nilson, A.A., Botelho, N.F., Ferreira Filho, C.F., 1994. Rifteamento crustal Meso-proterozóico no centro-norte de Goiás. In: Congr. Bras. de Geol., 38, Balneário de Camboriú (SC), SBG/SC, Anais..., Vol. 1, pp. 258-259.

Pimentel, M.M., 1990. Late Proterozoic crustal evolution of the Tocantins Province in Central Brazil: an isotopic and geochemistry study. Ph.D. Thesis, Oxford, England, Oxford University, p. 248.

Pimentel, M.M., Heaman, L., Fuck, R.A., Marini, O.J., 1991. U-Pb zircon geochronology of Precambrian tin-bearing continental-type acid magmatism in central Brazil. Precambrian Research 52, 321-335.

Pimentel, M.M., Heaman, L., Fuck, R.A., 1991. Zircon and sphene U-Pb geochronology of upper proterozoic volcanic-arc rock units from southwestern Goiás, Central Brazil. Journal of South America Earth Science 4 (4), 295-305.

Pimentel, M.M., Fuck, R.A., 1992. Neoproterozoic crustal accretion in central Brazil. Geology 20, 375-379.

Pimentel, M.M., Heaman, L., Fuck, R.A., 1992. Idade do meta-riolito da Seqüencia Maratá, Grupo Araxá, Goiás: estudo geocronológico pelos métodos U-Pb em zircão, Rb-Sr e Sm-Nd. An. Acad. Bras. Ci. 64 (1), 19-28.

Pimentel, M.M., Fuck, R A., Machado, N., Fuck, R.F., Ribeiro, R.K., Viana, M.G., 1993a. Dados geocronológicos $\mathrm{U}-\mathrm{Pb}$ preliminares da região de Mara Rosa (Goiás): implicações para a época de mineralização de Au e para a evolução tectônica Neoproterozóica no Centro-oeste. In: Congr. Bras. Geoquímica, 4, Brasília (DF), SBG/DF, Res. Expandidos, pp. 255-258.

Pimentel, M.M., Rodrigues, J.B., Fuck, R.A., Machado, N., 1993b. Idade U-Pb em zircões do metarriolito da Seqüência Vulcano-sedimentar de Iporá, oeste de Goiás. In: Congr. Bras. Geoquímica, 4, Brasília (DF), SBG/DF, Res. Expandidos, pp. 259-261.

Roig, H.L., Schrank, A., 1992. Caracterização da zona de sutura Jacuí-Conceição da Aparecida, limite norte do 
complexo de nappes de Guaxupé (MG). In: Congr. Bras. Geol., 37, São Paulo (SP), 1992, SBG-SP, Bol. Res. Exp..., Vol. 1, pp. 283-285.

Roscoe, J.S., Araújo Filho, J.O., 1994. Estudo estrutural preliminar do front de empurrão do Araxá sobre o Paranoá na porção oriental da Megainflexão dos Pirineus, Goiás Central. In: Simp. Reg. Geol. Centro-oeste, 4, Brasília (DF), SBG/BS-CO, Anais..., pp. 177-180.

Schobbenhaus Filho, C., Ribeiro, C.L., Oliva, L.A., Takanohashi, J.T., Lindenmayer, A.G., Vasconcelos, J.C., Orlandi Filho, V., 1975. Folha Goiás (SD 22). In: Schobbenhaus Filho C., coord., Carta Geológica do Brasil ao Milionésimo, Brasília, DNPM, pp. 15-84, 99-113, 1 mapa.

Schobbenhaus Filho, C., Campos, D.A., Derze, G.R., Asmus, H.E., 1984. Geologia do Brasil: testo explicativo do Mapa Geológico do Brasil e da área oceânica adjacente incluindo depósitos minerais (1:2500000). DNPM, Brasília (DF), $501 \mathrm{p}$.

Strieder, A.J., 1989. Geologia, Petrologia e Tectônica dos Corpos de Serpentinito e Rochas Encaixantes, Abadiânia (GO). Dissertação de Mestrado (IGeo-UnB), Brasília (DF), 208 p. (inédito).

Strieder, A.J., 1990. Análise estrutural na região de Abadiânia (GO). Rev. Bras. de Geoc. 20 (1-4), $239-257$.

Strieder, A.J., 1993a. Tectônica colisional no Brasil Central: evolução e implicações no padrão estrutural. In: Simp. Nac. Est. Tectônicos, 4, Belo Horizonte, 1993, Anais... Belo Horizonte, SBG/MG, pp. 297-301.

Strieder, A.J., 1993b. Deformação e metamorfismo na região de Santa Cruz de Goiás-Correlação tectono-estratigráfica e evolução tectônica regional. Tese de Doutoramento (IGeo-UnB), Brasília (DF), p. 258. (inédito).

Strieder, A.J., Nilson, A.A., 1992a. Melange ofiolítica nos metassedimentos Araxá de Abadiânia (GO) e implicações tectônicas regionais. Rev. Bras. Geoc. 22 (2), 204-215.

Strieder, A.J., Nilson, A.A., 1992b. Estudo petrológico de alguns fragmentos tectônicos da melange ofiolítica em Abadiânia (GO): I — o protolito dos corpos de serpentinito. Rev. Bras. Geoc. 22 (3), 338-352.

Strieder, A.J., Nilson, A.A., 1992c. Estudo petrológico...: II-as cromitas primárias e as suas transformações metamórficas. Rev. Bras. Geoc. 22 (3), 353-362.

Strieder, A.J., Nilson, A.A., 1992d. Estudo petrológico...: III-texturas e composição química dos corpos máficos. Rev. Bras. Geoc. 22 (3), 363-371.

Strieder, A.J., Nilson, A.A., 1993a. Abadiânia nappe emplacement and dispersion: some constraints on the evolution of Central Brazil. In: Simp. sobre o Cráton do São Francisco, 2, Salvador, 1993, Bol. Res. Exp., Salvador, SBG/BA, pp. 277-279.

Strieder, A.J., Nilson, A.A., 1993b. Análise preliminar de lineamentos na Província Estrutural do Tocantins. In: Simp. Nac. Est. Tectônicos, 4, Belo Horizonte, 1993, Anais... Belo Horizonte, SBG/MG, pp. 272-276.

Strieder, A.J., Nilson, A.A., 1994. Estratigrafia de terrenos precambrianos: o exemplo da Lâmina de Cavalgamento da Nappe de Abadiânia. In: Congr. Bras. de Geol., 38, Baln. Camboriú (SC), SBG/SC, 1994, Bol. Res. Exp., Vol. 3, pp. $257-258$

Strieder, A.J., Cunha, F.S.S., Gottardo, E., 1997. O registro e o significado tectônico de estruturas back thrust na Provincia Estrutural do Tocantins. In: Simpósio Nacional de Estudos Tectônicos, Pirenópolis (GO), SBG-DF, 1997, Bol. Resumos Expandidos, p. 7-9.

Strieder, A.J., Gottardo, E., Cunha, F.S.S., Binotto, R.B., Mesquita, M.J.M., 1994. O significado tectônico dos Lineamentos Transbrasilianos no processo colisional Neoproterozóico da Província Estrutural do Tocantins. In: Congr. Bras. de Geol., 38, Baln. Camboriú (SC), SBG/SC, 1994, Bol. Res. Exp., Vol. 1, pp. 143-145.

Suita, M.T.F., 1996. Metalogenia e Geoquímica de Platinóides em Alguns Complexos Máfico-ultramáficos no Brasil: alguns critérios e guias com ênfase no Complexo Máfico-ultramáfico de Barro Alto. Unpublished Thesis, Universidade Federal do Rio Grande do Sul (IG-UFRGS), Porto Alegre (RS-Brasil).

Suita, M.T.F., Chemale Jr., F., 1995. Nature of the Uruaçuano Cycle in the São Francisco and Tocantins Provinces and its relations with the Amazonian Craton. In: Simpósio Nacional de Estudos Tectônicos, 5, Gramado (RS), Extended Abstracts, SBG-RS, p. 98-100.

Suita, M.T.F., Kamo, S.L., Krogh, T., Fyfe, W.S., Hartmann, L.A., 1994a. U/Pb ages from the high-grade Barro Alto Mafic-ultramafic Complex (Goiás, Central Brazil): Middle Proterozoic Continental Mafic Magmatism and Upper Proterozoic Continental Collision. In: Lanphere, M.A., Dalrymple, G.B., Turrin, B.D. (Eds.), Abstracts, International Conference on Geochronology and Cosmochemistry, Berkeley (California, U.S.A.), U.S. Geological Survey, Circular $\mathrm{N}^{\circ} 1107$, p. 309.

Suita, M.T.F., Hartmann, L.A., Kamo, S.L., 1994b. The Nature of the Barro Alto Layered Mafic-ultramafic Complex 
and a discussion on the role of the Brasiliano and the Uruaçuano Cycles in Goiás, Central Brazil. In: Extended Abstracts, International Symposium on the Physics and Chemistry of the Upper Mantle, São Paulo (SP-Brasil), pp. 82-84.

Teixeira, L.B., Martins, M., Braun, O.P.G., 1993. Evolução geológica da Bacia do São Francisco com base em sísmica de reflexão e métodos potenciais. In: Simp. sobre o Cráton do São Francisco, 2, Salvador (BA), SBG/BA e SGM/BA, Anais..., pp. 179-181.

Thomaz Filho, A., Lima, V.Q., 1981. Datações radiométricas de rochas sedimentares pelíticas pelo método Rb/Sr. Bol, Técn. Petrobrás, Rio de Janeiro (RJ), Vol. 24, no. 2, pp. 109-119.

Vasconcellos, A.C.B.C., 1988. O Grupo Andrelândia na região norte de Ouro Fino (MG). Dissert. de Mestrado (IGUSP), São Paulo (SP), 199 p. (inédito).

Viana, M.G., Pimentel, M.M., 1994. Dados geoquímicos e isotópicos Sm-Nd preliminares para rochas metavulcânicas e metaplutônicas da região de Mara Rosa. In: Simp. Geol. Centro-oeste, 4, Brasília (DF), SBG/CO-BS, Anais..., pp. 148-151.

Wernick, E., Fiori, A.P., Bettencourt, J.S., Choudhuri, A., 1979. A tectônica rígida do fim do Ciclo Brasiliano e a sua implicação na estruturação da borda sul e sudoeste do Cráton do São Francisco: tentativa de um modelo preliminar. In: Simp. sobre o Cráton do São Francisco e suas faixas marginais, 1, Salvador (BA), SBG/BA, Anais..., pp. 164 168. 